\title{
Design considerations of an IL13Ra2 antibody-drug conjugate for diffuse intrinsic pontine glioma
}

\author{
Xiaolei Lian, Dina Kats, Samuel Rasmussen, Leah R. Martin, Anju Karki, Charles Keller ${ }^{*}$ and Noah E. Berlow ${ }^{*}$ (])
}

\begin{abstract}
Diffuse intrinsic pontine glioma (DIPG), a rare pediatric brain tumor, afflicts approximately 350 new patients each year in the United States. DIPG is noted for its lethality, as fewer than $1 \%$ of patients survive to five years. Multiple clinical trials involving chemotherapy, radiotherapy, and/or targeted therapy have all failed to improve clinical outcomes. Recently, high-throughput sequencing of a cohort of DIPG samples identified potential therapeutic targets, including interleukin 13 receptor subunit alpha 2 (IL13Ra2) which was expressed in multiple tumor samples and comparably absent in normal brain tissue, identifying IL13Ra2 as a potential therapeutic target in DIPG. In this work, we investigated the role of IL13Ra2 signaling in progression and invasion of DIPG and viability of IL13Ra2 as a therapeutic target through the use of immunoconjugate agents. We discovered that IL13Ra2 stimulation via canonical ligands demonstrates minimal impact on both the cellular proliferation and cellular invasion of DIPG cells, suggesting IL13Ra2 signaling is non-essential for DIPG progression in vitro. However, exposure to an anti-IL13Ra2 antibody-drug conjugate demonstrated potent pharmacological response in DIPG cell models both in vitro and ex ovo in a manner strongly associated with IL13Ra2 expression, supporting the potential use of targeting IL13Ra2 as a DIPG therapy. However, the tested ADC was effective in most but not all cell models, thus selection of the optimal payload will be essential for clinical translation of an anti-IL13Ra2 ADC for DIPG.
\end{abstract}

Keywords: Diffuse intrinsic pontine glioma, Antibody-drug conjugates, Immunotherapy, IL13Ra2, Pediatric cancer

\section{Introduction}

Approximately 350 children per year in the United States are diagnosed with the high-grade glioma (HGG) subtype denoted diffuse intrinsic pontine glioma (DIPG), which represents $16 \%$ of all pediatric and young adult central nervous system tumors $[17,22,52]$. The prognosis for DIPG patients is dire, with median survival lingering under 1 year and fewer than $1 \%$ of DIPG patients surviving to 5 years[50]. DIPG presents in the pons region of the midbrain as tumor nodules interwoven amongst normal

*Correspondence: charles@cc-tdi.org; noah@cc-tdi.org

Children's Cancer Therapy Development Institute, 12655 SW Beaverdam Road-West, Beaverton, OR 97005, USA tissue, making surgical removal impossible [40]. After initiation, DIPG cells disseminate and can invade into multiple brain regions and even into the spinal cord $[12,46]$. Standard clinical care for DIPG consists of 54-60 Gy local field radiotherapy dosed over 6 weeks which temporarily improves patient neurological function and extends survival by $2-3$ months [45], although resulting in lower quality of life due to negative long-term effects of radiation on pediatric brain function and development [8]. Despite investigation of multiple regimens based on chemotherapy, radiotherapy or next-generation targeted therapeutic agents, outcomes for DIPG remain essentially unchanged resulting in a disease marred by minimal long-term survivorship desperately in need of new targets and therapeutics $[9,14,18,20,21,27,29,38]$. Given the marginal advances give appropriate credit to the original author(s) and the source, provide a link to the Creative Commons licence, and indicate if changes were made. The images or other third party material in this article are included in the article's Creative Commons licence, unless indicated otherwise in a credit line to the material. If material is not included in the article's Creative Commons licence and your intended use is not permitted by statutory regulation or exceeds the permitted use, you will need to obtain permission directly from the copyright holder. To view a copy of this licence, visit http://creativecommons.org/licenses/by/4.0/. The Creative Commons Public Domain Dedication waiver (http://creativecommons.org/publicdomain/zero/1.0/) applies to the data made available in this article, unless otherwise stated in a credit line to the data. 
in clinical outcomes for DIPG, recent efforts to improve translational research have focused on high-throughput sequencing of available cohorts of patient-derived DIPG tissue samples which resulted in discovery of new targets for therapeutic intervention, including interleukin 13 receptor subunit alpha 2 (IL13R $\alpha 2)$ [7].

IL13R $\alpha 2$ is a cell-surface protein involved in regulation of interleukin 13 (IL-13) and interleukin 4 (IL-4) signaling [15]. IL13R $\alpha 2$ directly binds IL-13 as a monomer to induce IL13RA2 signaling [23], and IL13R $\alpha 2$ shows four orders-of-magnitude greater binding affinity for IL-13 than the alpha 1 receptor subunit (IL13R $\alpha 1$ ) [37]. Conversely, IL13RA2 is capable of associating with and regulating response of IL-4 only by acting in concert with IL-4R [2]. IL13R $\alpha 2$ signaling has been studied in the context of multiple diseases: IL13R $\alpha 2$ activates the focal adhesion kinase (FAK, also called PTK2) and phosphatidylinositol-4,5-bisphosphate 3-kinase (PI3K) pathways through the family with sequence similarity $120 \mathrm{~A}$ (FAM120A) scaffold protein [5] which mediates invasion and metastasis in colon cancer, IL-13 stimulation of IL13R $\alpha 2$ activates Transforming Growth Factor Beta 1 (TGF $\beta 1$ ) and induces allograft fibrosis [19], and IL13R $\alpha 2$ cooperates with epidermal growth factor receptor vIII (EGFRvIII) to promote the growth of glioblastoma multiforme (GBM) [43]. IL13R $\alpha 2$ has previously been identified as a target of interest in numerous cancers, including malignant gliomas [28,30,51], pancreatic cancer [23], melanoma [44], ovarian cancer [32], and colon cancer [5]. IL13R $\alpha 2$ has been explored clinically as both a CAR-T cell based therapy and as a phase III recombinant protein immunoconjugate target trial for adult glioma with promising outcomes $[10,11,33,34]$, supporting further investigation of immunotherapies or immunoconjugate therapies targeting IL13R $\alpha 2$ in other diseases with appropriate receptor expression patterns.

Antibody-drug conjugates (ADCs) are a novel class of immunoconjugate therapeutics which chemically link protein-specific antibodies with potent cytotoxic agents to target antigen-expressing cells with high specificity. Recently, FDA approved ADCs such as trastuzumab emtansine, trastuzumab emtansine [6], inotuzumab ozogamicin [31], and polatuzumab vedotin [49] are regarded as breakthrough therapeutics for breast cancer, Hodgkin's lymphoma, and acute lymphoblastic leukemia respectively, which subsequently resulted in initiation of numerous ADC-based clinical trials. Foremost among design considerations for new ADCs is identifying the cell surface antigen target for the $\mathrm{ADC}$, which requires both differentially elevated expression of the antigen target in tumor cells and internalization then degradation of the conjugated antibody to release the chemically-bound cytotoxic molecules [35].
In the context of DIPG, previous high-throughput transcriptome sequencing identified IL13R $\alpha 2$ as a DIPG-selective genetic target versus patient-derived normal brain tissue samples (17.32-fold overexpression, $\mathrm{p}=0.0003$ ) [7] and immunohistochemical (IHC) staining demonstrated $12 / 17$ samples (70.5\%) were positive for IL13R $\alpha 2$ of which $6 / 12(50.0 \%)$ showed medium or strong expression [7]. Similar expression patterns of IL13R $\alpha 2$ in DIPG and normal brain tissue have recently been independently confirmed [56]. Overexpression of IL13R $\alpha 2$ cell surface protein in cancerous cells and relative absence in normal tissue meets the first criteria of ADC design consideration and demonstrated internalization and degradation of both IL-13 and antiIL13R $\alpha 2$ antibody through IL13R $\alpha 2$ receptor binding $[5,10,11,16,33,34]$ meets the second criteria, suggesting an anti-IL13R $\alpha 2$ ADC may be a viable therapy for DIPG.

In this manuscript, we investigate the role of IL13RA2 in growth of DIPG and validate the potential of an antiIL13R $\alpha 2$ antibody-drug conjugate as a potential novel treatment for DIPG. The studies presented here demonstrate that direct stimulation of IL13R $\alpha 2$ through canonical ligands induces minimal effect on either cellular proliferation or cellular invasion of DIPG cells. Conversely, cell viability assays demonstrate strong association between elevated IL13R $\alpha 2$ expression and sensitivity to anti-IL13R $\alpha 2$ ADC agents, affirming the potential of IL13R $\alpha 2$ as a therapeutic target in DIPG.

\section{Materials and methods Cell models}

The following five cell models and associated growth media were used in the experiments performed for this study:

1. DIPG-6 cultured in complete tumor stem medium (TSM), defined below.

2. DIPG-17 cultured in complete TSM.

3. DIPG-24 cultured in complete TSM.

4. SF-8628 cultured in Dulbecco's Modified Eagle Medium (DMEM) (Cat \#11995065; Thermo Fisher Scientific, Waltham, MA, USA) supplemented with 1\% Penicillin/Streptomycin (P/S) (Cat \#15140122, Thermo Fisher Scientific) and 10\% fetal bovine serum (FBS) (Cat \#26140079; Thermo Fisher Scientific)

5. CHLA-200 cultured in Iscove's Modified Dulbecco's Medium (IMDM) (Cat \#12440061; Thermo Fisher Scientific) supplemented with $1 \% \mathrm{P} / \mathrm{S}, 10 \%$ FBS, 4 mM L-Glutamine (L-Glut) (Cat \#25030081; Thermo Fisher Scientific), and $1 \times$ Insulin-Transferrin-Selenium (ITS) (Cat \#41400045; Thermo Fisher Scientific) 
Cell model SF-8628 was also genetically modified to stably express luciferase and red fluorescent protein (RFP) using EF1a-Luciferase (firefly)-2A-RFP lentiviral particles (Cat \# LVP440; GenTarget Inc, San Diego, CA, USA), which were subsequently puromycin selected to isolate a purified luciferase/RFP positive cell population. All cell cultures were maintained in Nunc EasyFlask T75 (Cat \#156,499; Thermo Fisher Scientific) vented flasks stored in incubators set at $5 \% \mathrm{CO} 2$ at $37{ }^{\circ} \mathrm{C}$. Complete TSM is based on a previously published medium recipe for generation of patient-derived DIPG cell cultures [36]. Basal TSM consists of $250 \mathrm{~mL}$ Neurobasal-A (NBA) (Cat \#10888022; Thermo Fisher Scientific), 250 mL Dulbecco's Modified Eagle Medium/Nutrient Mixture F12 (DMEM/ F12) (Cat \#11330032; Thermo Fisher Scientific), $1 \times$ antibiotic-antimycotic (Cat \#15240096; Thermo Fisher Scientific), 2 mM GlutaMAX (Cat \#35050061; Thermo Fisher Scientific), $10 \mathrm{mM}$ HEPES (Cat \#15630080; Thermo Fisher Scientific), $1 \mathrm{mM}$ sodium pyruvate (Cat \#11360070; Thermo Fisher Scientific), and 1× MEM nonessential amino acids (Cat \#11140050; Thermo Fisher Scientific).

To create complete TSM media, basal TSM media is supplemented with $1 \times$ B-27 (Cat \#12587010; Thermo Fisher Scientific), $2 \mu \mathrm{g} / \mathrm{mL}$ Heparin (Cat \#07980; StemCell Technologies, Vancouver, BC, CA), $20 \mathrm{ng} / \mathrm{mL}$ recombinant human epidermal growth factor (EGF) (Cat \#100-26; Shenandoah Biotechnology, Warwick, PA, USA), $20 \mathrm{ng} / \mathrm{mL}$ recombinant human basic fibroblast growth factor (FGF-basic) (Cat \#100-26; Shenandoah Biotechnology), $10 \mathrm{ng} / \mathrm{mL}$ recombinant human platelet-derived growth factor glycoprotein A (PDGF-AA) (Cat \#100-16; Shenandoah Biotechnology), and $10 \mathrm{ng} /$ $\mathrm{mL}$ recombinant human platelet-derived growth factor glycoprotein B (PDGF-BB) (Cat \#100-18; Shenandoah Biotechnology).

Additional details for cell models used in this study, including IL13R $\alpha 2$ expression status, are provided in Table 1 . The human alveolar rhabdomyosarcoma cell line RH30 (accession ID CVCL_0041) was used solely for a supplemental experiment to validate the recombinant IL- 4 and IL-13 proteins used in this study. RH30 was cultured in Roswell Park Memorial Institute (RPMI) 1640 Medium (Cat \#12633012; Thermo Fisher Scientific) supplemented with $1 \% \mathrm{P} / \mathrm{S}$ and $10 \% \mathrm{FBS}$. All cell lines were tested for authenticity at their institute of origin and were additionally authenticated at initiation of study via short tandem repeat (STR) fingerprinting (Additional file 3: Table 1) performed by the University of Arizona Genetics Core, as well as being surveyed for changes to proliferation, morphology, or behavior.

\section{Immunoblotting}

Cells for immunoblotting were lysed in RIPA lysis and extraction buffer (Cat \#89901; Thermo Fisher Scientific) supplemented with HALT protease and phosphatase inhibitor cocktail (Cat \#78440; Thermo Fisher Scientific) following the manufacturer's protocol. Collected

Table 1 DIPG and GBM cell models used in studies

\begin{tabular}{|c|c|c|c|c|c|}
\hline Article Model Name & DIPG-6 & DIPG-17 & DIPG-24 & SF-8628 & CHLA-200 \\
\hline Official Name & SU-DIPG-VI & SU-DIPG-XVII & SU-DIPG-24 & SF8628 & CHLA-200 \\
\hline Accession ID & CVCL_IT40 & N/A & N/A & CVCL_IT46 & CVCL_M147 \\
\hline IL13Ra2 Status & IL13Ra2-High & IL13Ra2-High & IL13Ra2-Low & IL13Ra2-High & IL13Ra2-High \\
\hline Model Type & $\begin{array}{l}\text { Neurosphere Culture } \\
\text { (suspension) }\end{array}$ & $\begin{array}{l}\text { Neurosphere Culture (suspen- } \\
\text { sion) }\end{array}$ & $\begin{array}{l}\text { Neurosphere Culture } \\
\text { (generally adherent) }\end{array}$ & Cell Line (adherent) & Cell Culture (adherent) \\
\hline Growth Media & Complete TSM & Complete TSM & Complete TSM & DMEM + 1\% P/S + 10\% FBS & $\begin{array}{l}\text { IMDM }+1 \% \mathrm{P} / \mathrm{S}+20 \% \\
\mathrm{FBS}+4 \mathrm{mM} \\
\text { L-Glut }+1 \times \mathrm{ITS}\end{array}$ \\
\hline Age at diagnosis (years) & 7 & 8 & 6 & 5 & 12 \\
\hline Gender & Female & Male & Female & Female & Male \\
\hline Histology & $\mathrm{HGG}$ & DIPG & DIPG & DIPG & GBM \\
\hline H3 status & $\mathrm{H} 3.3 \mathrm{~K} 27 \mathrm{M}$ & $\mathrm{H} 3.3 \mathrm{~K} 27 \mathrm{M}$ & $\mathrm{H} 3.3 \mathrm{~K} 27 \mathrm{M}$ & $\mathrm{H} 3.3 \mathrm{~K} 27 \mathrm{M}$ & Unknown \\
\hline Grade & III & IV & IV & IV & IV \\
\hline Origin & Pons & Pons & Pons & Unknown & Parietal lobe \\
\hline Treatment & $\mathrm{XRT}+$ vorinostat & $\begin{array}{l}\text { XRT + bevacizumab; panobi- } \\
\text { nostat } \longrightarrow \text { XRT-> everolimus }\end{array}$ & XRT + bevacizumab & Unknown & XRT + chemotherapy \\
\hline Survival (months) & 6 & 13 & 8 & Unknown & Unknown \\
\hline Tissue Source & autopsy & autopsy & autopsy & surgical biopsy & autopsy \\
\hline Material Source & Monje Lab & Monje Lab & Monje Lab & EMD Millipore & COG Repository \\
\hline PMID & $25939062[25]$ & $28823557[47]$ & $28823557[47]$ & $23603901[13]$ & $22120608[54]$ \\
\hline
\end{tabular}


protein lysates were stored at $-80{ }^{\circ} \mathrm{C} .20 \mu \mathrm{g}$ of protein was loaded into the channel of an SDS-polyacrylamide gel electrophoresis (PAGE) gel, one channel per cell model. Electrophoresis-separated proteins were electrically transferred to PVDF membrane, washed in TBST buffer, and blocked in 5\% fat-free milk for $2 \mathrm{~h}$ at room temperature, then incubated with primary antibodies at $4{ }^{\circ} \mathrm{C}$ overnight. Following primary antibody blocking, specific signal was detected with species-appropriate horseradish peroxidase-conjugated secondary antibody using Clarity Western blot ECL Substrate (Cat \#1705061; Bio-Rad Laboratories, Hercules, CA, USA) and imaged using an IVIS Lumina II imaging system (Caliper Life Sciences, Hopkinton, MA, USA).

The following primary-secondary antibodies were used in the study: anti-IL13R $\alpha 2$ 2E10 clone primary (Cat \#WH0003598M1; Sigma-Aldrich, St. Louis, MO, USA) with Horse anti-Goat secondary (Cat \#PI-9500; Vector Laboratories, Burlingame, CA, USA), rabbit anti-STAT6 (D3H4) primary antibody (Cat\# 5397S; Cell Signaling Technology, Danvers, MA, USA) with goat anti-rabbit IgG secondary (Cat \#PI-1000; Vector Laboratories), rabbit anti-pSTAT6 primary antibody (Cat \#9361S, Cell Signaling Technology) with goat anti-rabbit IgG secondary, and anti-GAPDH primary (Cat \#PLA0302; SigmaAldrich) with horse anti-mouse secondary (Cat \#PI-2000; Vector Laboratories).

Western blot studies were completed in triplicate to ensure validity of protein expression trends.

\section{Ligand stimulation cell proliferation studies}

Cells in single-cell suspension were plated in a 96-well plate (Cat \#136101; Thermo Fisher Scientific) at $50 \mu \mathrm{L} /$ well model-specific starvation medium. SF-8628 was plated in DMEM $+1 \% \mathrm{P} / \mathrm{S}$ at 500 cells/well, DIPG-24 was plated in TSM $+1 \times$ B27 $+2 \mu \mathrm{g} / \mathrm{mL}$ Heparin at 1500 cells/ well. Cells were starved overnight, then supplemented with recombinant human IL-4 (Cat \#100-09; Shenandoah Biotechnology) or recombinant human IL-13 (Cat \#10085; Shenandoah Biotechnology) to final concentrations of $0.5 \mathrm{ng} / \mathrm{mL}, 1 \mathrm{ng} / \mathrm{mL}, 5 \mathrm{ng} / \mathrm{mL}, 10 \mathrm{ng} / \mathrm{mL}, 50 \mathrm{ng} / \mathrm{mL}$, and $100 \mathrm{ng} / \mathrm{mL}$ at a final volume of $100 \mu \mathrm{L} /$ well. Negative control wells were supplemented $50 \mu \mathrm{L} /$ well starvation medium ( - CTRL), positive control wells were supplemented with $50 \mu \mathrm{L} /$ well double concentration growth media to reach final concentration of $1 \times$ growth media (+CTRL). Cells were incubated for $72 \mathrm{~h}$ then assayed with CellTiter Glo Luminescent Cell Viability Assay (Cat \#G7570, Promega, Madison, WI, USA) per the manufacturer's protocol. Luminescence was measured using a BioTek Synergy HT plate reader (BioTek, Winooski, VT). Cell growth was plotted in GraphPad Prism.
All stimulation experiments were performed with in triplicate for each treatment condition, with each experiment performed with three technical replicates for each cell model.

\section{IL-4 and IL-13 recombinant protein validation studies}

RH30 cells were plated in $6 \mathrm{~cm}$ plates and serum starved overnight in RPMI-1640 media with $1 \% \mathrm{P} / \mathrm{S}$. Cells were then exposed for $60 \mathrm{~min}$ to $20 \mathrm{ng} / \mathrm{mL}$ recombinant IL-4 in RPMI-1640 + 1\% P/S, $20 \mathrm{ng} / \mathrm{mL}$ recombinant IL-13 in RPMI-1640 + 1\% P/S, or RPMI- $1640+1 \% \mathrm{P} / \mathrm{S}$ (control). Cells were then harvested as described in the Immunoblotting section and probed for overall STAT6 level and phosphor-STAT6 level to confirm phosphorylation of STAT6 following IL-4 or IL-13 exposure, similar to a previously published study [26]. Validation stimulation experiments were performed in triplicate for each treatment condition.

\section{Cell invasion studies}

$6.5 \mathrm{~mm}$ transwell inserts with $8 \mu \mathrm{m}$ pores (Cat \#662638; Greiner Bio-One, Kremsmünster, Austria) were treated $0.1 \mathrm{~mL}$ of $300 \mu \mathrm{g} / \mathrm{mL}$ Matrigel (Cat \#35423; Corning Life Sciences, Tewksbury, MA, USA), placed in 24-well cell culture plates (Cat \#662160; Greiner Bio-One), and incubated for $30 \mathrm{~min}$ at $37{ }^{\circ} \mathrm{C}$. Next, cell models suspended in $300 \mu \mathrm{L}$ starvation media at specific cell populations were plated into each insert: SF-8628 at 50,000 cells/insert, CHLA-200 at 50,000 cells/insert, and DIPG-24 at 100,000 cells/insert. The lower wells were plated with $600 \mu \mathrm{L}$ media with the following experimental conditions: starvation media (-CTRL): SF-8628, DMEM + 1\% P/S; DIPG-24, TSM + 1× B-27 $+2 \mu \mathrm{g} / \mathrm{mL}$ Heparin; IMDM $+1 \times$ ITS $+2 \times$ L-Glutamate $+1 \% \mathrm{P} / \mathrm{S}$ (-CTRL), recombinant human IL-13 at concentrations of $20 \mathrm{ng} / \mathrm{mL}, 50 \mathrm{ng} / \mathrm{mL}, 100 \mathrm{ng} / \mathrm{mL}$ final concentration, or growth media $(+\mathrm{CTRL})$. Plates were then incubated for $72 \mathrm{~h}$ at $37^{\circ} \mathrm{C}$ with $5 \% \mathrm{CO}_{2}$.

The inserts were removed, aspirated, washed with twice with $\mathrm{H}_{2} \mathrm{O}$ and PBS, and the inside of the inserts were swabbed to remove non-invasive cells. Remaining cells were fixed with $4 \%$ paraformaldehyde (PFA) for 20 min then washed with PBS and $\mathrm{DDH}_{2} \mathrm{O}$. Fixed cells were stained with $0.1 \%$ crystal violet in $10 \%$ methanol for $20 \mathrm{~min}$, washed twice with $\mathrm{DDH}_{2} \mathrm{O}$, then allowed to dry overnight. Fixed, dried inserts were treated with $250 \mu \mathrm{L}$ of $10 \%$ acetic acid and then crystal violet intensity was quantified using a BioTek Synergy HT plate reader at $595 \mathrm{~nm}$ read wavelength. Cell invasion was plotted in GraphPad Prism.

All invasion experiments were performed in triplicate for each treatment condition, with each experiment 
performed with three technical replicates for each cell model.

\section{Primary antibody-secondary antibody-drug conjugate cell viability studies}

Cells suspended in appropriate growth media were plated into 96-well plates at $100 \mu \mathrm{L} /$ well at specific populations: SF-8628 at 750 cells/well, CHLA-200 at 750 cells/well, DIPG-6 at 1500 cells/well, DIPG-17 at 1500 cells/well, and DIPG-24 at 1500 cells/well. Plates were allowed to rest overnight, then exposed to $15 \mathrm{ng} / \mathrm{mL}$ anti-IL13R $\alpha 2$ $2 \mathrm{E} 10$ primary antibody, incubated at $37^{\circ} \mathrm{C}$ with $5 \% \mathrm{CO}_{2}$ for $10 \mathrm{~min}$, and finally treated with Fragment antigenbinding (Fab) fragments of anti-mouse IgG fragment crystallizable $(\mathrm{Fc})$ specific antibody conjugated to duocarmycin DM via non-cleavable linker (Fab- $\alpha$ MFc-CLDMD) (Cat \#AM-202-DD; Moradec LLC., San Diego, CA, USA) in the following concentrations: $0.2 \mathrm{pg} / \mathrm{mL}$, $0.9 \mathrm{pg} / \mathrm{mL}, 4.8 \mathrm{pg} / \mathrm{mL}, 24 \mathrm{pg} / \mathrm{mL}, 120 \mathrm{pg} / \mathrm{mL}, 600 \mathrm{pg} / \mathrm{mL}$, $3 \mathrm{ng} / \mathrm{mL}$, and $15 \mathrm{ng} / \mathrm{mL}$. Plates were incubated at $37^{\circ} \mathrm{C}$ with $5 \% \mathrm{CO}_{2}$ for $120 \mathrm{~h}$ then assayed with CellTiter Glo Luminescent Cell Viability Assay per the manufacturer's protocol. Luminescence was measured using a BioTek Synergy HT plate reader. Cell viability versus ADC concentration was plotted and $\mathrm{IC}_{50}$ values were calculated using GraphPad Prism.

All cell viability experiments were performed in triplicate for each treatment condition, with each experiment performed with three technical replicates for each cell model.

\section{Antibody Conjugations}

Antibody conjugation was performed by Moradec, LLC. IL13R $\alpha 2$ 2E10 antibody was concentrated to approximately $2 \mathrm{mg} / \mathrm{mL}$. $0.1 \mathrm{~mL}$ of concentrated antibody was used for initial conjugation optimizations to reach drugantibody ratio (DAR) around 3-4, then the remaining antibody was used to carry out the conjugation with maleimide-valine-alanine-Pyrrolobenzodiazepine (MalVA-PBD). The conjugation was a maleimide-cysteine based method by first reducing the antibody inter-chain disulfide bonds with TCEP and then linking the maleimide moiety of the drug to the reduced cysteines to generate the ADC. The conjugated ADC was desalted on Sephadex G50 columns to remove residual unreactive toxins and then buffer exchanged pH 7.2 in PBS. The final DAR was calculated from the A333nm:A280nm ratio and was determined to be 3.36 for anti-IL13R $\alpha 2::$ PBD.

\section{Antibody-drug conjugate in vitro cell viability studies} Cells suspended in appropriate growth media were plated into 96 -well plates at $150 \mu \mathrm{L} /$ well at specific populations:
SF-8628 at 750 cells/well, CHLA-200 at 750 cells/well, DIPG-6 at 1500 cells/well, DIPG-17 at 1500 cells/well, and DIPG-24 at 1500 cells/well. Plates were incubated overnight, then exposed to anti-IL13R $\alpha 2:: \mathrm{PBD}$ ADC at the following concentrations: $0 \mathrm{ng} / \mathrm{mL}, 1 \mathrm{ng} / \mathrm{mL}, 10 \mathrm{ng} /$ $\mathrm{mL}, 20 \mathrm{ng} / \mathrm{mL}, 100 \mathrm{ng} / \mathrm{mL}, 200 \mathrm{ng} / \mathrm{mL}, 1 \mu \mathrm{g} / \mathrm{mL}, 2 \mu \mathrm{g} /$ $\mathrm{mL}, 5 \mu \mathrm{g} / \mathrm{mL}, 10 \mu \mathrm{g} / \mathrm{mL}$. Plates were incubated at $37^{\circ} \mathrm{C}$ with $5 \% \mathrm{CO}_{2}$ for $144 \mathrm{~h}$ then assayed with CellTiter Glo Luminescent Cell Viability Assay per the manufacturer's protocol. Luminescence was measured using a BioTek Synergy HT plate reader. Cell viability versus ADC concentration was plotted and $\mathrm{IC}_{50}$ values were calculated using GraphPad Prism.

All cell viability experiments were performed in triplicate for each treatment condition, with each experiment performed with three technical replicates for each cell model.

\section{Antibody-drug conjugate ex ovo cell viability studies}

Fertilized Coturnix japonica (Japanese quail) eggs were purchased from Boyd's Bird Company (Eagle Creek, OR, USA) and Purely Poultry (Fremont, WI, USA), stored at $4{ }^{\circ} \mathrm{C}$ for $120 \mathrm{~h}$, and then incubated at $37^{\circ} \mathrm{C}$ and $70 \%$ humidity for approximately $54 \mathrm{~h}$ in an egg incubator. Quail eggs were opened by our mechanical device [48] into six-well plates (Cat \# CC Plate-PS-6A-F-CS; Advangene, Lake Bluff, IL, USA), then incubated for $112 \mathrm{~h}$ (embryonic day 7 ) at which point unfertilized/nonviable quail were removed.

Cultured and trypsinized luciferase/RFP-expressing SF-8628 cells were added to hydrogel-c (Cat \#GS313; ESI-BIO, Alameda, CA, USA) to a cell concentration of 5,000 cells/ $\mu \mathrm{L}$. Anti-IL13R $\alpha 2::$ PBD ADC carried in PBS was added to SF-8628-containing hydrogel, to final ADC concentrations of $0 \mathrm{ng} / \mathrm{mL}$ (PBS control), $50 \mathrm{ng} / \mathrm{mL}$ ( $\mathrm{n}=7$ quail), $500 \mathrm{ng} / \mathrm{mL}$ ( $\mathrm{n}=7$ quail), $5 \mu \mathrm{g} / \mathrm{mL}$ ( $\mathrm{n}=10$ quail), and $50 \mu \mathrm{g} / \mathrm{mL}$ ( $\mathrm{n}=8$ quail). $25 \mu \mathrm{L}$ of each treatment concentration was added to $6.5 \mathrm{~mm}$ diameter sterilized fiberglass 3D meshes (Cat \#SC-S510-0001; LenaBioscience, Atlanta, GA, USA) according to manufacturer's protocol then incubated for approximately $30 \mathrm{~min}$ at $37{ }^{\circ} \mathrm{C}$ and $100 \%$ humidity.

The chorioallantoic membrane (CAM) of viable quails were superficial injured by carefully placing and carefully removing an Eppendorf tube lid against the CAM. The mesh tumor modules were placed on the injury site and incubated for $120 \mathrm{~h}$. Add the end of the incubation, $100 \mu \mathrm{l}$ of PBS containing $1.5 \mathrm{mg}$ of luciferin-d (Cat \#122799; PerkinElmer, Waltham, MA, USA) was added to the tumor modules, incubated in the dark for $5 \mathrm{~min}$, and resulting bioluminescence was measured using an IVIS Lumina (PerkinElmer). The quail were imaged with a $15 \mathrm{~s}$ exposure for total light emission. Total light 
emission amongst ADC treatment concentrations were normalized to control emission to determine final SF-8268 cell viability.

\section{Statistics}

Dunnett's multiple comparisons test performed in GraphPad Prism was used to analyze statistical differences in cytokine stimulation cell proliferation assays and in cytokine stimulation cell invasion assays. Testing for linear trend was performed in GraphPad Prism to determine if cell proliferation by cytokine stimulation occurred in a dose-dependent manner.

\section{Results}

IL13Ra2 is expressed in DIPG tumor samples and cell models

We expanded the cohort of sequenced DIPG transcriptomes by incorporating newly-published RNA sequencing data from ten (10) DIPG tumor samples and two (2) normal pons tissue samples [41]. Evaluation of the expanded cohort confirmed the status of IL13R $\alpha 2$ overexpression, with the combined new dataset and previous dataset $(n=28$ DIPG tumor samples, $n=18$ normal tissue samples) demonstrating 21-fold overexpression in matched tumor vs. normal brain tissue and 12-fold overexpression in all tumor vs. normal samples $(\mathrm{p}<0.0001)$ (Fig. 1a, b), remaining significantly higher $(\mathrm{p}=0.01)$ than a

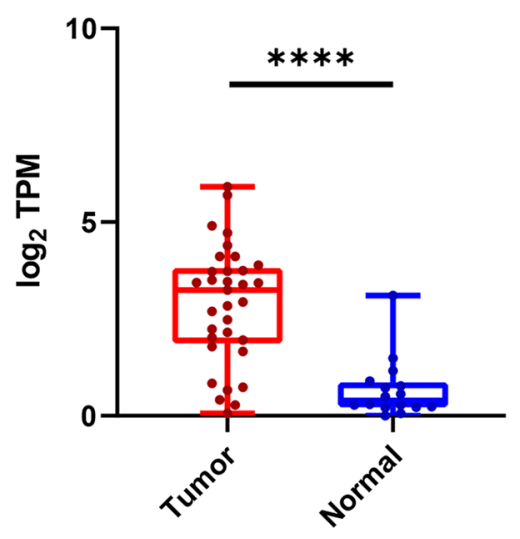

C

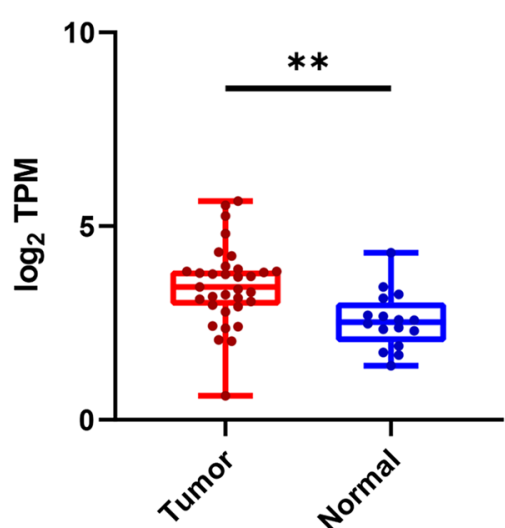

b

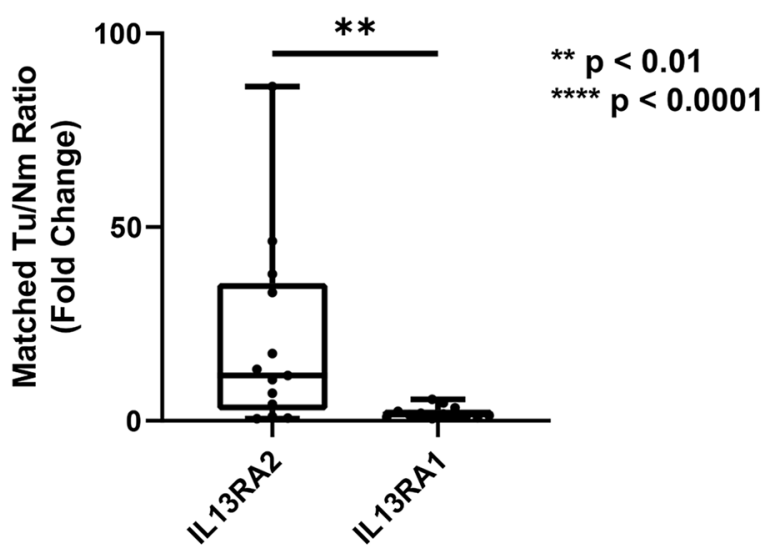

d

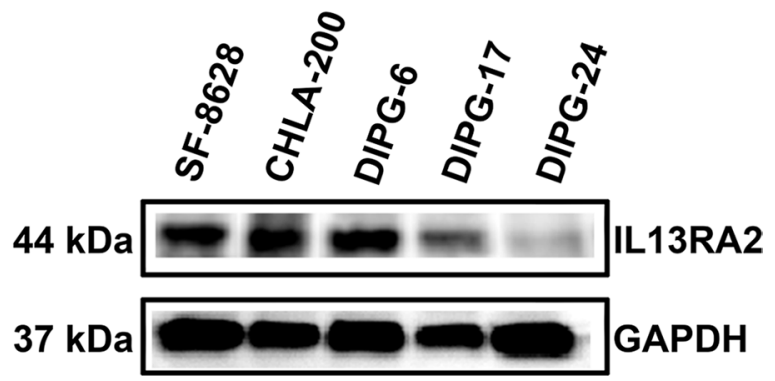

Fig. 1 Gene expression in DIPG. High-throughput RNA sequencing of 33 DIPG tumor samples vs. 20 normal brain samples across two cohorts. a IL13Ra2 tumor expression versus normal expression $(\mathrm{p}<0.01)$. b Tumor-normal expression ratios of IL13Ra2 and IL13Ra1 across patient-matched DIPG samples ( $p<0.01)$. $\mathbf{c}$ IL13Ra2 tumor expression versus normal expression $(p<0.0001)$. $\mathbf{d}$ Expression of IL13Ra2 in DIPG and GBM cell models (HEK293 as positive control) determined by immunoblotting. SF-8628, CHLA-200, DIPG-6, and DIPG-17 are IL13Ra2-high models, while DIPG-24 is IL13Ra2-low 
the tumor-normal expression ratio of IL13R $\alpha 1$ (Fig. 1b, c).

Subsequently, available DIPG cell models were assayed for protein-level expression of IL13R $\alpha 2$ to determine optimal models for further in vitro investigation. A list of cell models used in this study are provided in Table 1. Several cell models show strong IL13R $\alpha 2$ expression, including CHLA-200, DIPG-6, DIPG-13, DIPG-17, and SF-8628 (Fig. 1d), while DIPG-24 shows notably lower (but not absent) IL13R $\alpha 2$ expression.

\section{Functional impact of IL13Ra2 in DIPG growth and invasion}

Given the overexpression of IL13R $\alpha 2$ and the importance of the receptor in other diseases, we first investigated the role of IL13RA2 signaling in DIPG. To determine if cytokine stimulation modifies cell growth in vitro, cells were serum- or supplement-starved for $24 \mathrm{~h}$ then treated with varying concentrations of the known cytokine binding partners of IL13R $\alpha 2$, IL-4 and IL-13 (Fig. 2a-d). Of the cell model-cytokine combinations tested, only SF-8628 stimulated with IL-13 demonstrated any significant increase in cell growth versus starvation media as the negative control (Fig. 2b). Notably, the increased cell growth from IL-13 stimulation of SF-8628 was statistically dose-dependent (slope $=0.0215, \mathrm{p}<0.0001$ ). All other combinations demonstrated no statistically significant change in cell viability (Fig. 2a, c, d). Lack of DIPG-24 response is consistent with the lower expression of IL13R $\alpha 2$ in the assayed cell models, as DIPG-24 has reduced expression compared to SF-8628. However, no cell model showed increase in growth comparable to standard growth media (+CTRL). While IL-13 may impact growth rate of a single cell model the effect is negligible compared to optimal growth conditions, and IL-4 demonstrated no significant impact on growth. We confirmed expected mechanistic activity of the IL- 4 and IL-13 recombinant proteins by replicating a previously published study [26] (Additional file 2: Fig. 2).

Development of new DIPG tumor nodules both within the pons and throughout the CNS is critical to disease progression and mortality, thus we also investigated the effect of IL-13 stimulation on the invasive potential of DIPG/GBM cell models. As IL13R $\alpha 2$ is significantly more selective for IL-13 and because IL-13 demonstrated a modest but statistically significant impact on growth versus starvation media, we focused on the impact of IL-13 on cellular invasion[37]. We assayed two IL13R $\alpha 2$-high cell models (SF-8628 and CHLA-200) and one IL13R 2 -low cell model (DIPG24) to determine if IL-13 stimulation impacted cellular invasion in a dose-dependent manner (Fig. 2e-g).
Neither the IL13R $\alpha 2$-high nor IL13R $\alpha 2$-low cell models showed any statistically significant change in cell invasion following IL-13 stimulation versus negative control. Conversely, cells treated with standard growth media (+CTRL) demonstrated a statistically significant increase in invasion, showing the propensity for the cell models to invade in proper conditions.

\section{Pharmacological testing of IL13Ra2-targeting therapeutics in DIPG}

Having determined that exposure to canonical IL13R $\alpha 2$ ligands resulted in minimal impact on cell proliferation and invasion, we investigated the pharmacological response of DIPG/GBM cell models to IL13R $\alpha 2$ antibody-based agents. As a first-pass proof-of-concept experiment, we used a primary antibody+secondary antibody::cytotoxic agent system to test if IL13R $\alpha 2$ expression conferred sensitivity to IL13R $\alpha 2$ targeting agents. We selected four DIPG cell models and one GBM cell model (Table 1) for the proof-of-concept experiments. Cells were exposed to fixed concentrations of IL13R $\alpha 2$ 2E10 primary antibody in combination with varying concentrations of a secondary antibody conjugated to duocarmycin, a potent cytotoxic agent commonly conjugated to ADCs (Additional file 1: Fig. 1a). While the results did not show a direct relationship between IL13R $\alpha 2$ expression and duocarmycin sensitivity, two models showed stronger response (SF-8628 and CHLA-200), demonstrating that IL13R $\alpha 2$ expression can confer sensitivity to antibody-based therapies.

We theorized that the inability of IL13Ra2 antibodymediated cytotoxin delivery to decrease cell viability in some models was due to failure of duocarmycin to overcome innate chemoresistance of most DIPG cell models. To interrogate this possibility, we selected a IL13Ra2-high and one IL13Ra2-low cell model (SF-8628 and DIPG-24, respectively) and treated them with two commonly used and readily accessible ADC payloads, DM- 1 (also called mertansine) and monomethyl auristatin $\mathrm{F}$ (MMAF). SF-8628 was sensitive to both MMAF $\left(\mathrm{IC}_{50}=3.84 \mu \mathrm{M}\right.$, Additional file 1: Fig. $1 \mathrm{~b})$ and $\mathrm{DM}-1 \quad\left(\mathrm{IC}_{50}=82.5 \mathrm{nM}\right.$, Additional file 1: Fig. 1c), while DIPG-24 showed negligible sensitivity to (MMAF, Additional file 1: Fig. 1b) and slight sensitivity to DM-1 (Additional file 1: Fig. 1c). Disparity in cellular response to potent single agent cytotoxics suggests that selection of the payload agent may be critical for the effectiveness of any ADC developed to eliminate DIPG cells.

Partially positive results from the proof-of-concept experiments supported the continued evaluation of IL13R $\alpha 2$ as a target for ADC therapies in DIPG; thus, we developed a fully conjugated antibody::cytotoxic agent for experimental validation. As previously mentioned, 


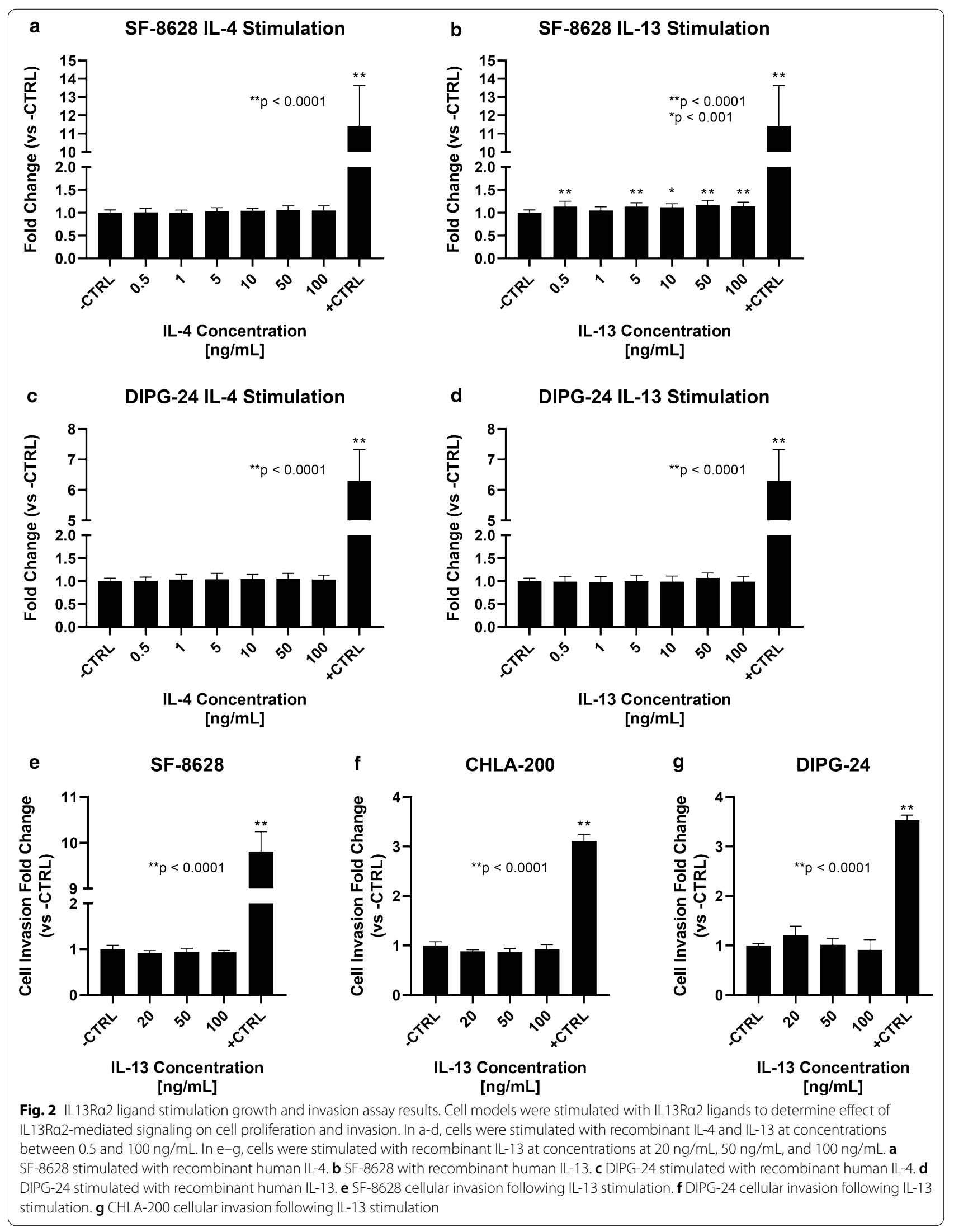


a critical challenge of DIPG treatment is the clinicallydemonstrated resistance to most standard chemotherapeutic agents and the failure of most clinical trials $[9,14,18,20,21,27,29,38]$, also reflected in the varied efficacy of the ADC cytotoxic agents tested on the DIPG cell models (Additional file 1: Fig. 1b, c). Thus, we selected pyrrolobenzodiazepine (PBD) as the payload for the IL13R $\alpha 2$ ADC as PBD is known to promote cell death in model systems often resistant to standard chemotherapy agents or standard ADC cytotoxic payloads[39].

We validated the activity of the anti-IL13R $\alpha 2:: \mathrm{PBD}$ ADC using the same cell models used in previous experiments (Table 1). Results from the cell viability assays demonstrate that three of four IL13R $\alpha 2$-positive cell models (CHLA-200, DIPG-17, and SF-8628) were highly sensitive to anti-IL13R $\alpha 2:: \mathrm{PBD}$, with all three cell models reaching $50 \%$ cell viability below $100 \mathrm{ng} / \mathrm{mL}$ ADC concentration and under $10 \%$ cell viability at highest tested ADC concentrations (Fig. 3a). One IL13R $\alpha 2-$ high cell model showed lesser response to the ADC

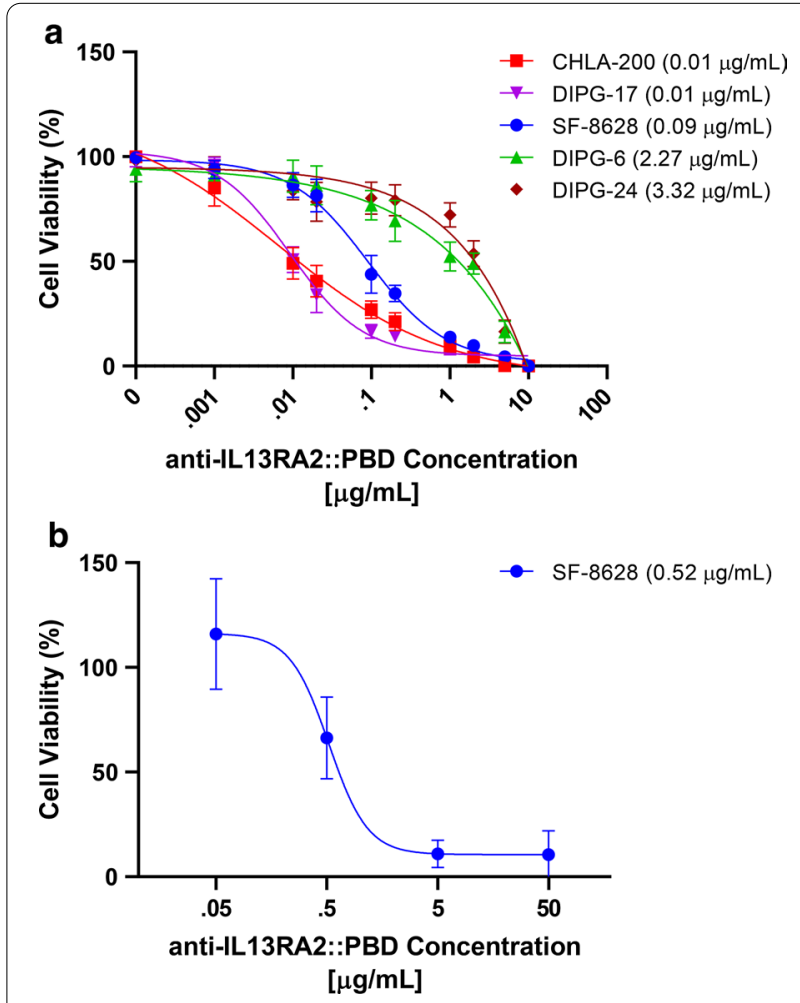

Fig. 3 Results from anti-IL13Ra2::PBD ADC cell viability assays in DIPG/GBM cell models. a Cell viability following incubation with anti-IL13Ra2::PBD ADC for four DIPG cell models (DIPG-17, SF-8628, DIPG-6, DIPG-24) and one GBM cell model (CHLA-200). Values in parentheses are $I C_{50}$ values. $\mathbf{b}$ Cell viability of SF-8628 ex ovo xenograft following anti-IL13Ra2::PBD ADC treatment. The value in parentheses is the $I_{50}$ value. Dose response points represent minimum $n=7$ quail per concentration
(DIPG-6, $\mathrm{IC}_{50}=2.27 \mu \mathrm{g} / \mathrm{mL}$ ), which could potentially be attributed to DIPG- 6 often demonstrating resistance to many agents[25]. The IL13R $\alpha 2$-low cell model also demonstrated lesser response to the ADC (DIPG-24, $\mathrm{IC}_{50}=3.32 \mu \mathrm{g} / \mathrm{mL}$ ) consistent with the lower (but not absent) expression of IL13R $\alpha 2$.

Finally, we tested the efficacy of the anti-IL13R $\alpha 2:: \mathrm{PBD}$ $\mathrm{ADC}$ in a luciferase/RFP-expressing SF-8628 quail ex ovo xenograft, with the ADC again showing strong response and a clear dose-dependent response $\left(\mathrm{IC}_{50}=0.59 \mu \mathrm{g} / \mathrm{mL}\right.$ ) in the immunoprivileged ex ovo model system (Fig. 3b). Overall, anti-IL13R $\alpha 2::$ PBD drug response associates well (4/5 models tested) with IL13R $\alpha 2$ expression in DIPG and positive response successfully translates to an ex ovo xenograft system.

\section{Discussion}

Relatively few treatments exist for DIPG, with the majority of clinical trials having demonstrated little to no improvement in clinical outcomes. Previous investigations of IL13R $\alpha 2$ as a therapeutic target by various treatment modalities $[10,11,33,34]$ suggest the utility of IL13R $\alpha 2$ targeting in the context of an immunotherapy or immunoconjugate for multiple diseases, including DIPG. However, overall clinical experience using CAR-T cell therapy in brain tumors has identified barriers to advancement. Specifically, the milieu of immune inflammatory responses to CAR-T cell therapy (termed CAR T-related encephalopathy syndrome, CRES) are often life-threatening toxicities [1]. While ADC therapies can also potentially illicit immunogenic responses, clinical use of bevacizumab monoclonal antibody therapy in glioblastoma has demonstrated a reduced need for corticosteroids as a consequence of treatment [24] suggesting monoclonal antibodies (and by extension ADC agents) may have lessened immunogenicity in brain tumors compared to CAR-T cell therapy. Additionally, brain tumor microenvironments are frequently immunosuppressive [1], which may be less challenging to an ADC operating through cytotoxicity-induced apoptosis compared to CAR-T cell therapy which requires immune cell involvement.

From our studies, three key points can be taken from the exploration of IL13R $\alpha 2$ as a therapeutic target in DIPG. First, stimulation by both IL13R $\alpha 2$ cytokine binding partners (IL-4 and especially the canonical ligand IL-13) demonstrate negligible effect on cell proliferation or invasion, suggesting that IL13R $\alpha 2$ binding and signaling may not be essential to DIPG progression, thus even inadvertent stimulation of this pathway through the use of an ADC is unlikely to negatively impact the course of treatment. Second, high expression of IL13R $\alpha 2$ in DIPG 
and GBM associates strongly with sensitivity to antiIL13R $\alpha 2::$ PBD ADC, although PBD may have limitations in killing more resistant DIPG cell models as PBD acts through inducing DNA damage [55]. Finally, as antiIL13R $\alpha 2::$ PBD demonstrates efficacy in most but not all DIPG models, the selection of the cytotoxic payload will be critical for the success of any ADC developed for DIPG.

The negligible impact on either cell proliferation or invasion is somewhat surprising, given previous studies demonstrating IL13RA2 acting as a strong mediator of both proliferation and invasion in multiple diseases $[4,23,43]$. In glioblastoma, IL13RA2 has been shown to cooperate with mutant EGFRvIII to mediate growth [43], while EGFR mutations including EGFRvIII are believed to not be widely recurrent in DIPG $[25,53]$ which may limit the importance of IL13RA2 in DIPG progression. Additionally, a separate study performed in our laboratory explored the effect of multiple receptor-ligand pairs highly expressed in DIPG and known to impact proliferation in other disease, with the majority of canonical signaling pairs demonstrating similarly limited impact on DIPG cell proliferation and invasion (manuscript in preparation).

Despite the positive correlation between antiIL13R $\alpha 2::$ PBD ADC sensitivity and IL13R $\alpha 2$ expression status, DIPG-6 insensitivity to the ADC exemplifies the key challenge in designing ADC therapeutics for DIPG. A key requirement in the design of a clinical ADC is selecting an exceedingly potent cytotoxic capable of affecting cellular death at low $(\sim 10 \mathrm{nM})$ concentrations, as ADC efficacy is heavily linked to payload efficacy [42]. While the innate chemoresistance of DIPG may be somewhat abrogated by PBD's ability to overcome chemoresistance, PBD still operates via DNA damage mechanisms similar to duocarmycin [55] and thus selecting a non-standard ADC payload may potentially overcome the resistance seen in DIPG-6 and potentially other DIPG cell models.

Nonetheless, the promising proof-of-concept results of anti-IL13R $\alpha 2::$ PBD ADC in DIPG present a translational opportunity. There are currently no clinicallyvalidated therapeutics available for DIPG, nor are there any FDA approved IL13R $\alpha 2$ immunoconjugate agents. Successful translation of an IL13R $\alpha 2$ ADC for DIPG would provide a promising new therapeutic to a pediatric disease which lacks any viable life-saving treatment options and would enable broader clinical use of an immunoconjugate agent for a cell surface target overexpressed in numerous cancer types. Moving an IL13R $\alpha 2$ ADC to clinical use will require optimizing the antibody binding dynamics and maximizing efficacy of the cytotoxic payload while minimizing peripheral toxicity, optimizations which are the requisite next steps for initiation of an anti-IL13R $\alpha 2$ ADC clinical trial for DIPG. Fortunately, convectionenhanced delivery (CED) of an antibody is already known to be clinically feasible[3]. Overall, despite the potential limitations of PBD as the cytotoxic payload, anti-IL13R $\alpha 2$ ADC agents show promise as a therapeutic strategy for an exceptionally intractable disease such as DIPG.

\section{Supplementary Information}

The online version contains supplementary material available at https://doi. org/10.1186/s40478-021-01184-9.

Additional file 1: Figure 1. Cell model response to exploratory immunoconjugate experiments. Cell viability results following a primary antibodysecondary antibody immunoconjugate assay as well as two cytotoxic agents commonly used as ADC payloads. Cytotoxic agents were tested on SF-8628 and DIPG-24. Values in parentheses are $I_{50}$ values. a) Cell viability following two-step incubation of anti-IL13Ra2 primary antibody plus a duocarmycin-conjugated secondary antibody. b) Cell viability following treatment with unconjugated MMAF. c) Cell viability following treatment with unconjugated DM-1.

Additional file 2: Figure 2. Validation of mechanistic function of IL-4 and IL-13 recombinant proteins. Human alveolar rhabdomyosarcoma cell line $\mathrm{RH} 30$ was exposed to $20 \mathrm{ng} / \mathrm{mL} \mathrm{IL}-4$ or $\mathrm{IL}-13$ recombinant protein for $60 \mathrm{~min}$. STAT6 expression and phosphorylation was detected via western blot to confirm expected activity of recombinant proteins based on previously published studies [26]. Control RH30 demonstrates no phosphorylation of STAT6, while both IL-4 and IL-13 exposure induce STAT6 phosphorylation, as expected.

Additional file 3: Table 1. Table of information, properties, and clinical and genomic characteristics for cell lines used in this study.

\section{Acknowledgements}

We thank Dr. Michelle Monje from Stanford University for the use of DIPG cell lines DIPG-6 (SU-DIPG-VI), DIPG-17 (SU-DIPG-XVII), and DIPG-24 (SU-DIPG-24), and the Children's Oncology Group Cell Line Repository (Dr. Anat ErdreichEpstein and Dr. Patrick Reynolds) for the use of the CHLA-200 cell line and the $\mathrm{RH} 30$ cell line. Author NEB is co-founder of First Ascent Biomedical, a for-profit corporation. The work in this study is completely distinct from the work at Flrst Ascent Biomedical.

\section{Authors' contributions}

Designed and performed experiments: XL, DK, SR, LKM, AK, NEB. Assisted with manuscript preparation: XL, DK, SR, CK, NEB. Prepared materials for experiments: XL, DK, SR, LKM, AK, NEB. Oversaw the study: CK, NEB.

\section{Funding}

This study was funded by a grant from the Matthew Larson Foundation for Pediatric Brain Tumors, as well as donations in honor of Caleb Caleb, Nicole, and Andrew.

\section{Availability of data and materials}

Transcriptome sequencing data is available through the Database of Genotypes and Phenotypes (dbGaP) under accession IDs phs000900.v1.p1 and phs001526.v1.p1, and through the European Genome-Phenome Archive (EGA) under accession ID EGAD00001006450. 


\section{Declarations}

Ethics approval and consent to participate

Not applicable.

\section{Consent for publication}

Not applicable.

\section{Competing interests}

Author CK is a co-founder of Artisan Biopharma, a wholly-owned public benefit corporation of the Children's Cancer Therapy Development Institute (cc-TDI). CK through cc-TDI also has research frameworks or collaborations with Roche Genentech, Eli Lilly, and Novartis. The chorioallantoic membrane (CAM) assay process is being developed for patenting and commercialization by authors CK and SR. The remaining authors declare no competing interests.

Received: 10 February 2021 Accepted: 18 April 2021

Published online: 17 May 2021

\section{References}

1. Akhavan D, Alizadeh D, Wang D, Weist MR, Shepphird JK, Brown CE (2019) CAR T cells for brain tumors: lessons learned and road ahead. Immunol Rev 290:60-84. https://doi.org/10.1111/imr.12773

2. Andrews AL, Nasir T, Bucchieri F, Holloway JW, Holgate ST, Davies DE (2006) IL-13 receptor alpha 2: a regulator of IL-13 and IL-4 signal transduction in primary human fibroblasts. J Allergy Clin Immunol 118:858-865. https://doi.org/10.1016/j.jaci.2006.06.041

3. Bander ED, Ramos AD, Wembacher-Schroeder E, Ivasyk I, Thomson R, Morgenstern PF, Souweidane MM (2020) Repeat convection-enhanced delivery for diffuse intrinsic pontine glioma. J Neurosurg Pediatr. https:// doi.org/10.3171/2020.6.peds20280

4. Barderas R, Bartolomé RA, Fernandez-Aceñero MJ, Torres S, Casal II (2012) High expression of IL-13 receptor a2 in colorectal cancer is associated with invasion, liver metastasis, and poor prognosis. Can Res 72:27802790. https://doi.org/10.1158/0008-5472.can-11-4090

5. Bartolomé RA, García-Palmero I, Torres S, López-Lucendo M, Balyasnikova IV, Casal JI (2015) IL13 receptor a2 signaling requires a scaffold protein, FAM120A, to activate the FAK and PI3K pathways in colon cancer metastasis. Can Res 75:2434-2444. https://doi.org/10.1158/0008-5472. can-14-3650

6. Beck A, Goetsch L, Dumontet C, Corvaïa N (2017) Strategies and challenges for the next generation of antibody-drug conjugates. Nat Rev Drug Discov 16:315-337. https://doi.org/10.1038/nrd.2016.268

7. Berlow NE, Svalina MN, Quist MJ, Settelmeyer TP, Zherebitskiy V, Kogiso M, Qi L, Du Y, Hawkins CE, Hulleman E et al (2018) IL-13 receptors as possible therapeutic targets in diffuse intrinsic pontine glioma. PLoS ONE 13:e0193565-e0193565. https://doi.org/10.1371/journal.pone.0193565

8. Bledsoe JC (2016) Effects of cranial radiation on structural and functional brain development in pediatric brain tumors. J Pediatr Neuropsychol 2:3-13. https://doi.org/10.1007/s40817-015-0008-2

9. Bouffet E, Raquin M, Doz F, Gentet JC, Rodary C, Demeocq F, Chastagner P, Lutz P, Hartmann O, Kalifa C (2000) Radiotherapy followed by high dose busulfan and thiotepa: a prospective assessment of high dose chemotherapy in children with diffuse pontine gliomas. Cancer 88:685-692. https://doi.org/10.1002/(SICI)1097-0142(20000201)88:3\%3c685::AIDCNCR27\%3e3.0.CO;2-K[pii]

10. Brown CE, Alizadeh D, Starr R, Weng L, Wagner JR, Naranjo A, Ostberg JR, Blanchard MS, Kilpatrick J, Simpson J et al (2016) Regression of glioblastoma after chimeric antigen receptor T-cell therapy. N Engl J Med 375:2561-2569. https://doi.org/10.1056/NEJMoa1610497

11. Candolfi M, Xiong W, Yagiz K, Liu C, Muhammad AKMG, Puntel M, Foulad D, Zadmehr A, Ahlzadeh GE, Kroeger KM et al (2010) Gene therapymediated delivery of targeted cytotoxins for glioma therapeutics. Proc Natl Acad Sci USA 107:20021-20026. https://doi.org/10.1073/pnas.10082 61107

12. Caretti $V$, Bugiani $M$, Freret $M$, Schellen $P$, Jansen $M$, van Vuurden $D$, Kaspers G, Fisher PG, Hulleman E, Wesseling P et al (2014) Subventricular spread of diffuse intrinsic pontine glioma. Acta Neuropathol 128:605607. https://doi.org/10.1007/s00401-014-1307-x

13. Chan KM, Fang D, Gan H, Hashizume R, Yu C, Schroeder M, Gupta N, Mueller S, James CD, Jenkins R et al (2013) The histone H3.3K27M mutation in pediatric glioma reprograms H3K27 methylation and gene expression. Genes Dev 27:985-990. https://doi.org/10.1101/gad.217778.113

14. Cohen KJ, Heideman RL, Zhou T, Holmes EJ, Lavey RS, Bouffet E, Pollack IF (2011) Temozolomide in the treatment of children with newly diagnosed diffuse intrinsic pontine gliomas: a report from the Children's Oncology Group. Neuro Oncol 13:410-416. https://doi.org/10.1093/neuonc/ noq205

15. David M, Ford D, Bertoglio J, Maizel AL, Pierre J (2001) Induction of the IL-13 receptor alpha2-chain by IL-4 and IL-13 in human keratinocytes: involvement of STAT6, ERK and p38 MAPK pathways. Oncogene 20:6660-6668. https://doi.org/10.1038/sj.onc.1204629

16. Debinski W, Dickinson P, Rossmeisl JH, Robertson J, Gibo DM (2013) New agents for targeting of IL-13RA2 expressed in primary human and canine brain tumors. PLoS ONE 8:e77719-e77719. https://doi.org/10.1371/journ al.pone.0077719

17. Donaldson SS, Laningham F, Fisher PG (2006) Advances toward an understanding of brainstem gliomas. J Clin Oncol 24:1266-1272. https://doi. org/10.1200/JCO.2005.04.6599

18. Dunkel IJ, O'Malley B, Finlay JL (1996) Is there a role for high-dose chemotherapy with stem cell rescue for brain stem tumors of childhood? Pediatr Neurosurg 24:263-266

19. Fichtner-Feigl S, Strober W, Kawakami K, Puri RK, Kitani A (2006) IL-13 signaling through the IL-13alpha2 receptor is involved in induction of TGF-beta1 production and fibrosis. Nat Med 12:99-106. https://doi.org/ 10.1038/nm1332

20. Finlay $\mathrm{L}$, August C, Packer R, Zimmerman R, Sutton L, Freid A, Rorke L, Bayever E, Kamani N, Kramer E et al (1990) High-dose multi-agent chemotherapy followed by bone marrow "rescue" for malignant astrocytomas of childhood and adolescence. J Neurooncol 9:239-248

21. Finlay $\mathrm{J}$, Zacharoulis S (2005) The treatment of high grade gliomas and diffuse intrinsic pontine tumors of childhood and adolescence: a historical- and futuristic-perspective. J Neurooncol 75:253-266

22. Freeman CR, Farmer JP (1998) Pediatric brain stem gliomas: a review. Int J Radiat Oncol Biol Phys 40:265-271

23. Fujisawa T, Joshi B, Nakajima A, Puri RK (2009) A novel role of interleukin-13 receptor alpha2 in pancreatic cancer invasion and metastasis. Can Res 69:8678-8685. https://doi.org/10.1158/0008-5472.can-09-2100

24. Gramatzki D, Roth P, Rushing EJ, Weller J, Andratschke N, Hofer S, Korol D, Regli L, Pangalu A, Pless M et al (2018) Bevacizumab may improve quality of life, but not overall survival in glioblastoma: an epidemiological study. Ann Oncol 29:1431-1436. https://doi.org/10.1093/annonc/mdy106

25. Grasso CS, Tang Y, Truffaux N, Berlow NE, Liu L, Debily M-A, Quist MJ, Davis LE, Huang EC, Woo PJ et al (2015) Functionally defined therapeutic targets in diffuse intrinsic pontine glioma. Nat Med 21:555-559. https:// doi.org/10.1038/nm.3855

26. Hosoyama T, Aslam MI, Abraham J, Prajapati SI, Nishijo K, Michalek JE, Zarzabal LA, Nelon LD, Guttridge DC, Rubin BP et al (2011) IL-4R drives dedifferentiation, mitogenesis, and metastasis in rhabdomyosarcoma. Clin Cancer Res 17:2757-2766. https://doi.org/10.1158/1078-0432. ccr-10-3445

27. Jalali R, Raut N, Arora B, Gupta T, Dutta D, Munshi A, Sarin R, Kurkure P (2010) Prospective evaluation of radiotherapy with concurrent and adjuvant temozolomide in children with newly diagnosed diffuse intrinsic pontine glioma. Int J Radiat Oncol Biol Phys 77:113-118. https://doi.org/ 10.1016/j.jijrobp.2009.04.031

28. Jarboe JS, Johnson KR, Choi Y, Lonser RR, Park JK (2007) Expression of interleukin-13 receptor a 2 in glioblastoma multiforme: implications for targeted therapies. Can Res 67:7983-7986

29. Jennings MT, Sposto R, Boyett JM, Vezina LG, Holmes E, Berger MS, Bruggers CS, Bruner JM, Chan KW, Dusenbery KE et al (2002) Preradiation chemotherapy in primary high-risk brainstem tumors: phase II study CCG-9941 of the Children's Cancer Group. J Clin Oncol 20:3431-3437

30. Joshi BH, Plautz GE, Puri RK (2000) Interleukin-13 receptor alpha chain: a novel tumor-associated transmembrane protein in primary explants of human malignant gliomas. Can Res 60:1168-1172

31. Kantarjian HM, DeAngelo DJ, Stelljes M, Liedtke M, Stock W, Gökbuget N, O'Brien SM, Jabbour E (2019) Inotuzumab ozogamicin versus standard of 
care in relapsed or refractory acute lymphoblastic leukemia: Final report and long-term survival follow-up from the randomized, phase 3 INO-VATE study. 125: 2474-2487. https://doi.org/10.1002/cncr.32116

32. Kioi M, Kawakami M, Shimamura T, Husain SR, Puri RK (2006) Interleukin-13 receptor alpha2 chain: a potential biomarker and molecular target for ovarian cancer therapy. Cancer 107:1407-1418. https://doi.org/10. 1002/cncr.22134

33. Kunwar S, Chang S, Westphal M, Vogelbaum M, Sampson J, Barnett G, Shaffrey M, Ram Z, Piepmeier J, Prados M et al (2010) Phase III randomized trial of CED of IL13-PE38QQR vs Gliadel wafers for recurrent glioblastoma. Neuro Oncol 12:871-881. https://doi.org/10.1093/neuonc/ nop054

34. Kunwar S, Prados MD, Chang SM, Berger MS, Lang FF, Piepmeier JM, Sampson JH, Ram Z, Gutin PH, Gibbons RD et al (2007) Direct intracerebral delivery of cintredekin besudotox (IL13-PE38QQR) in recurrent malignant glioma: a report by the Cintredekin Besudotox Intraparenchymal Study Group. J Clin Oncol 25:837-844. https://doi.org/10.1200/jco. 2006.08.1117

35. Lambert JM, Berkenblit A (2018) Antibody-drug conjugates for cancer treatment. Annu Rev Med 69:191-207. https://doi.org/10.1146/annur ev-med-061516-121357

36. Lin GL, Monje M (2017) A protocol for rapid post-mortem cell culture of diffuse intrinsic pontine glioma (DIPG). J Vis Exp. https://doi.org/10.3791/ 55360

37. Lupardus PJ, Birnbaum ME, Garcia KC (2010) Molecular basis for shared cytokine recognition revealed in the structure of an unusually high affinity complex between IL-13 and IL-13Ralpha2. Structure 18:332-342. https://doi.org/10.1016/j.str.2010.01.003

38. MacDonald TJ, Aguilera D, Kramm CM (2011) Treatment of high-grade glioma in children and adolescents. Neuro Oncol 13:1049-1058. https:// doi.org/10.1093/neuonc/nor092

39. Mantaj J, Jackson PJM, Rahman KM, Thurston DE (2017) From anthramycin to pyrrolobenzodiazepine (PBD)-containing antibody-drug conjugates (ADCs). Angew Chem Int Ed Engl 56:462-488. https://doi.org/ 10.1002/anie.201510610

40. Mathew RK, Rutka JT (2018) Diffuse intrinsic pontine glioma : clinical features, molecular genetics, and novel targeted therapeutics. J Korean Neurosurg Soc 61:343-351. https://doi.org/10.3340/jkns.2018.0008

41. Nagaraja S, Quezada MA, Gillespie SM, Arzt M, Lennon JJ, Woo PJ, Hovestadt V, Kambhampati M, Filbin MG, Suva ML et al (2019) Histone variant and cell context determine H3K27M reprogramming of the enhancer landscape and oncogenic state. Mol Cell 76:965-980.e912. https://doi.org/10.1016/j.molcel.2019.08.030

42. Nejadmoghaddam M-R, Minai-Tehrani A, Ghahremanzadeh R, Mahmoudi M, Dinarvand R, Zarnani A-H (2019) Antibody-drug conjugates: possibilities and challenges. Avicenna J Med Biotechnol 11:3-23

43. Newman JP, Wang GY, Arima K, Guan SP, Waters MR, Cavenee WK, Pan E, Aliwarga E, Chong ST, Kok CYL et al (2017) Interleukin-13 receptor alpha 2 cooperates with EGFRvIll signaling to promote glioblastoma multiforme. Nat Commun 8:19013. https://doi.org/10.1038/s41467-017-01392-9

44. Okamoto H, Yoshimatsu Y, Tomizawa T, Kunita A, Takayama R, Morikawa T, Komura D, Takahashi K, Oshima T, Sato M et al (2019) Interleukin-13 receptor $\mathrm{a} 2$ is a novel marker and potential therapeutic target for human melanoma. Sci Rep 9:1281. https://doi.org/10.1038/s41598-019-39018-3

45. Packer RJ, Allen JC, Goldwein JL, Newall J, Zimmerman RA, Priest J, Tomita T, Mandelbaum DE, Cohen BH, Finlay JL et al (1990) Hyperfractionated radiotherapy for children with brainstem gliomas: a pilot study using 7,200 cGy. Ann Neurol 27:167-173. https://doi.org/10.1002/ana.41027 0212

46. Panditharatna E, Yaeger K, Kilburn LB, Packer RJ, Nazarian J (2015) Clinicopathology of diffuse intrinsic pontine glioma and its redefined genomic and epigenomic landscape. Cancer Genet 208:367-373. https://doi.org/ 10.1016/j.cancergen.2015.04.008

47. Qin EY, Cooper DD, Abbott KL, Lennon J, Nagaraja S, Mackay A, Jones C, Vogel H, Jackson PK, Monje M (2017) Neural precursor-derived pleiotrophin mediates subventricular zone invasion by glioma. Cell 170:845-859. e819. https://doi.org/10.1016/j.cell.2017.07.016

48. Rasmussen SV, Berlow NE, Price LH, Mansoor A, Cairo S, Rugonyi S, Keller C (2020) Preclinical therapeutics ex ovo (in Preparation)

49. Sehn LH, Herrera AF, Flowers CR, Kamdar MK, McMillan A, Hertzberg M, Assouline S, Kim TM, Kim WS, Ozcan M et al (2020) Polatuzumab vedotin in relapsed or refractory diffuse large B-cell lymphoma. J Clin Oncol 38:155-165. https://doi.org/10.1200/jco.19.00172

50. Smith SE, Waller JC, Bingham IA, Jewett DM, Nsouli MS, Mackintosh JJ (2014) A diffuse intrinsic pontine glioma roadmap: guiding research toward a cure. Pediatr Blood Cancer 61:765-767. https://doi.org/10.1002/ pbc. 24923

51. Tu M, Wange W, Cai L, Zhu P, Gao Z, Zheng W (2016) IL-13 receptor alpha2 stimulates human glioma cell growth and metastasis through the $\mathrm{Src} /$ PI3K/Akt/mTOR signaling pathway. Tumour Biol 37:14701-14709. https:// doi.org/10.1007/s13277-016-5346-x

52. Ueoka DI, Nogueira J, Campos JC, Maranhao Filho P, Ferman S, Lima MA (2009) Brainstem gliomas-retrospective analysis of 86 patients. J Neurol Sci 281:20-23. https://doi.org/10.1016/j.jns.2009.03.009

53. Wu G, Diaz AK, Paugh BS, Rankin SL, Ju B, Li Y, Zhu X, Qu C, Chen X, Zhang $J$ et al (2014) The genomic landscape of diffuse intrinsic pontine glioma and pediatric non-brainstem high-grade glioma. Nat Genet 46:444-450. https://doi.org/10.1038/ng.2938

54. Xu J, Erdreich-Epstein A, Gonzalez-Gomez I, Melendez EY, Smbatyan G, Moats RA, Rosol M, Biegel JA, Reynolds CP (2012) Novel cell lines established from pediatric brain tumors. J Neurooncol 107:269-280. https:// doi.org/10.1007/s11060-011-0756-5

55. Yu B, Liu D (2019) Antibody-drug conjugates in clinical trials for lymphoid malignancies and multiple myeloma. J Hematol Oncol 12:94. https://doi. org/10.1186/s13045-019-0786-6

56. Zeng J, Zhang J, Yang Y-Z, Wang F, Jiang H, Chen H-D, Wu H-Y, Sai K, Hu W-M (2020) IL13RA2 is overexpressed in malignant gliomas and related to clinical outcome of patients. Am J Transl Res 12:4702-4714

\section{Publisher's Note}

Springer Nature remains neutral with regard to jurisdictional claims in published maps and institutional affiliations.
Ready to submit your research? Choose BMC and benefit from:

- fast, convenient online submission

- thorough peer review by experienced researchers in your field

- rapid publication on acceptance

- support for research data, including large and complex data types

- gold Open Access which fosters wider collaboration and increased citations

- maximum visibility for your research: over 100M website views per year

At BMC, research is always in progress.

Learn more biomedcentral.com/submissions 